\title{
Knowledge, prevalence and seroconversion for hepatitis B in health professionals acting in a private clinic
}

\author{
Adriana Della BETTA ${ }^{1}$, Claudinei Mesquita da SILVA ${ }^{1}$, Jorge Vieira TEIXEIRA ${ }^{2}$, Leyde Daiane de PEDER ${ }^{1}$ \\ ${ }^{1}$ Clinical Analyses Laboratory, University Center of Assis Gurgacz Foundation, Cascavel, Paraná, Brazil. ²Department of Clinical Analysis and \\ Biomedicine and Post-Graduate Program in Biosciences and Physiopathology, Maringá State University, Maringá, Paraná, Brazil.
}

Corresponding author: Peder LD, leydepeder@yahoo.com.br

Submitted: 02-02-2019 Resubmitted: 15-01-2020 Accepted: 11-02-2020

Peer review: blind reviewers

\begin{abstract}
Objective: The aim of the present study was to evaluate the knowledge, prevalence and seroconversion to hepatitis $B$ in health professionals. Methods: A descriptive and quantitative research was conducted through the application of questionnaires, examination analysis and immunization records of employees of a private health clinic in Cascavel, Paraná. Results: Of the 96 employees, 87 (90.6\%) had anti-HBs reagent verified by the exam. Of these, the majority of employees were female (91.6\%), had knowledge of the hepatitis $\mathrm{B}$ virus (HBV) (96.3\%) and were between 31 and 40 years old (47.4\%). Also, they had not had an accident with biological material (86.5\%), had no HBV carrier (87.4\%), or had had contact with carriers of the infection (90.6\%). Conclusion: Although the most effective prevention method against HBV is vaccination, approximately $10 \%$ of the employees did not have antibodies detected by the test. In addition, some individuals showed little knowledge about hepatitis $B$, which is of concern, as they are health professionals who are at risk of acquiring infections due to contact with patients and biological materials.
\end{abstract}

Keywords: hepatitis B, sexually transmitted infections, vaccination, immunity.

\section{Conhecimento, prevalência e soroconversão para hepatite B em profissionais de saúde que atuam em uma clínica privada}

\begin{abstract}
Resumo
Objetivo: Avaliar o conhecimento, prevalência e soroconversão para hepatite B em profissionais de saúde. Métodos: Realizou-se uma pesquisa descritiva e quantitativa por meio da aplicação de questionários, análise de exames e registros de imunização de funcionários de uma clínica de saúde privada de Cascavel, Paraná. Resultados: Do total de 96 funcionários, 87 (90,6\%) apresentaram anti-HBs reagente verificado pelo exame. Destes, a maioria dos funcionários era do sexo feminino (91,6\%), possuía conhecimento sobre o vírus da hepatite B (VHB) (96,3\%) e tinha entre 31 e 40 anos (47,4\%). Também, não haviam passado por acidente com material biológico (86,5\%), não eram portadores do VHB (87,4\%), nem tinham tido contato com portadores da infeç̧ão (90,6\%). Conclusão: Embora o método de prevenção mais eficaz contra o VHB seja a vacinação, aproximadamente $10 \%$ dos funcionários não apresentaram anticorpos detectados pelo exame, além disso, alguns indivíduos demonstraram pouco conhecimento sobre a hepatite B, o que traz preocupação, pois são profissionais de saúde que estão expostos ao risco de adquirir infecções devido ao contato com os pacientes e com materiais biológicos.
\end{abstract}

Palavras-chave: hepatite B, infecções sexualmente transmissíveis, vacinação, imunidade.

\section{Introduction}

According to the World Health Organization (WHO), it is estimated that worldwide in 2017, approximately 325 million people were infected with the hepatitis B virus (HBV) and with the hepatitis $\mathrm{C}$ virus $(\mathrm{HCV})$, a figure ten times greater than the number of people infected with the human immunodeficiency virus (HIV), and most of these carriers are asymptomatic ${ }^{1,2}$. The global report on hepatitis in 2017 indicates that the vast majority of people do not have access to tests and consequently treatment, which can make diagnosis and cure more difficult and leaves millions of people at risk of a slow progression to chronic liver disease, cancer and death ${ }^{1,3,4}$.

HBV infection has significant variations in prevalence and incidence depending on the geographic region. It is a major health problem, which requires monitoring and awareness 5 . From 1999 to 2017, 218,257 cases of hepatitis B in Brazil were confirmed and notified. Of these, the majority is concentrated in the Southeast (35.2\%), 
followed by the South (31.6\%), North (14.3\%), Northeast (9.7\%), and Midwest $(9.2 \%)^{4,5}$.

In health workers, the prevalence of the hepatitis B viral infection varies from 4.8 to $11.1 \%$ and may be up to three times higher than in the general population, which can be justified by the high risk of occupational exposure ${ }^{6}$. Factors such as presence and volume of blood, clinical conditions of the source patient, and correct use of post-exposure prophylaxis can influence the risk of contamination ${ }^{7}$.

An important aspect in relation to protection against HBV is the confirmation of seroconversion, which is performed by the serological test for anti-HBs measurement. This identifies the presence of antibodies against HBV in the individual's blood, thus being used to assess the effectiveness of the vaccine schedule $e^{8,9}$ Ignorance of seroconversion causes delay in prevention and control measures in the event of an eventual accident with biological material, since the conduct to be taken after exposure depends on the result of this test and other tests to be performed, often resulting in a combination of medicated cocktail for the prophylaxis of other diseases ${ }^{9}$.

It is known that $90 \%$ of the people have seroconversion after completing the complete vaccination schedule. Thus, existing and developing prevention programs seem to be promising in terms of decreasing the prevalence of infection ${ }^{5,10}$. Along with seroconversion, it is important to have knowledge about the ways of transmission of the virus, which collaborates in prevention and also in ensuring protection for health professionals.

According to Lima et al (2013), the professionals working in the nursing field are the workers most likely to acquire and transmit infections, such as hepatitis B due to exposure to blood and other biological fluids ${ }^{11}$. This exposure is related to the professional's direct contact with the patient, often with infections, in addition to the high frequency with which the nursing procedures are performed with the patient in the hospital setting.

A study by Morais et al (2016) showed a high prevalence rate of HBV infection in health professionals, suggesting that the practice of nursing in the hospital setting is an important risk factor for occupational infection. In addition, professionals with longer time of practice and age, a history of accidents with biological material, and a history of blood transfusion are more susceptible to HBV infection ${ }^{12}$. From that, the aim of this study was to evaluate knowledge, prevalence and seroconversion for hepatitis B among the professionals working in a private health clinic located in Cascavel, Paraná

\section{Methods}

An epidemiological research of a descriptive character and with a quantitative approach, carried out through the collection of data from anti-HBs tests and registration of immunizations, as well as a questionnaire applied to employees of a private health clinic located in the municipality of Cascavel, state of Paraná (PR), during the month of September 2018. All the employees hired and working in the clinic during the study period were considered for the study.

The clinic performs elective care with the scheduling of surgical procedures in the areas of gynecology and obstetrics, orthopedics, gastrointestinal, plastic, oncology, and vascular surgery. It currently has 100 employees, of whom two are under 18 years old (minor apprentice), two are on leave and 96 are active. The employees who work in the clinic and agreed to participate in the research work in the different sectors of the same.

The following variables of interest were collected: results of antiHBs tests (reagent or non-reagent present in the filed reports) and vaccination for hepatitis $B$ (presence and number of doses described in the immunization records). The following information was collected in the questionnaires: age, gender, ethnicity, schooling, number of sexual partners in the last 12 months, use of condoms, use of tobacco, use of alcohol, knowledge about seroconversion (presence of knowledge, lack of knowledge or without knowledge), contact with patients with hepatitis $B$ (occupational, sexual or co-living), use of piercings, performing or having tattoos, performing blood transfusion, knowledge about ways of prevention and ways of infection.

To define knowledge about the infection, the following question was asked: "What do you know about preventing hepatitis B?" It was defined as "Total" knowledge, when employees answered three or more correct questions about the infection; as "Partial", when they provided one or two correct answers and as "No knowledge", when they provided incorrect information or when they answered nothing.

The collected data were stored in Microsoft Excel ${ }^{\circledR}$ and the statistical analysis was performed using the Bioestat ${ }^{\circledR} 2.0$ software. The distribution of quantitative variables was categorized. The results were expressed in frequencies and percentages. The categorical variables were compared between the groups using the Chi-square test. The level of significance was set at $p<0.05$.

This study was approved by the Research Ethics Committee of the University Center of the Assis Gurgacz Foundation, under opinion number 063893/2018 of June $12^{\text {th }}, 2018$ (CAAE: 91292518.9.0000.5219). In accordance with the ethical principles in research with human beings, precautions were taken so that the confidentiality and privacy of the subjects involved in the study were preserved.

\section{Results}

Among the 100 employees of the clinic, 96\% participated in the research and signed the Free and Informed Consent Form. Two of the four excluded employees were under the age of 18. and two were on sick leave. Of the $96,87(90.6 \%)$ had antibodies to the hepatitis B virus and 9 (9.4\%) had no antibodies, as identified in the anti-HBs tests. Of the non-reactants in the anti-HBs test, $5(55.5 \%)$ have already repeated the vaccination schedule. Of the employees, all had a partial or complete immunization record, with hepatitis $B$ vaccine and periodic examination filed in the clinic's Human Resources department.

There was knowledge about the presence of very similar seroconversion between men and women and between individuals of different ages and ethnicities. The absence of seroconversion or the fact of not knowing whether or not to have antibodies against the hepatitis B virus differed between gender, age and ethnicity, as defined in Table 1, which shows the epidemiological characteristics of the employees according to the knowledge collected in a questionnaire regarding the presence of immunity. By analyzing the anti-HBs test, it was found that most of the employees had seroconversion to hepatitis $B$; however, some were unable to report. 
Table 1. Correlation between sociodemographic characteristics of the employees working in a private clinic located in Cascavel, PR and knowledge of seroconversion for hepatitis $B$

\begin{tabular}{lccc}
\hline Characteristics & $\begin{array}{c}\text { Knowledge of } \\
\text { the presence of } \\
\text { seroconversion } \\
\mathbf{n}(\%)\end{array}$ & $\begin{array}{c}\text { Knowledge of } \\
\text { the absence of } \\
\text { seroconversion } \\
\mathbf{n}(\%)\end{array}$ & $\begin{array}{c}\text { Did not know } \\
\text { how to report } \\
\text { seroconversion } \\
\mathbf{n}(\%)\end{array}$ \\
\hline Age (years old) & $14(66.7)$ & $4(19,0)$ & $3(14.3)$ \\
$20-30$ & $25(64.1)$ & $9(23.1)$ & $5(12.8)$ \\
$31-40$ & $20(66.7)$ & $5(16.6)$ & $5(16.6)$ \\
$41-50$ & $4(66.8)$ & $0(0.0)$ & $2(33.3)$ \\
$\leq 51$ & & & \\
Gender & $5(62.5)$ & $1(12.5)$ & $2(25.0)$ \\
Male & $56(63.6)$ & $18(20.5)$ & $14(15.9)$ \\
Female & $43(65.2)$ & $12(18.2)$ & $11(16.6)$ \\
Ethnicity & $4(66.7)$ & $1(16.6)$ & $1(16.6)$ \\
White & $15(62.2)$ & $5(21.7)$ & $3(13.0)$ \\
Black & $0(0.0)$ & $0(0.0)$ & $1(100.0)$ \\
Mixed & & & \\
Others & $2(33.3)$ & $3(50.0)$ & $1(16.7)$ \\
Alcohol consumption & $71(70.7)$ & $7(12.0)$ & $10(17.3)$ \\
Yes & $20(62.5)$ & $7(21.9)$ & $5(15.6)$ \\
No & & & \\
Socially & $3(50.0)$ & $1(16.5)$ & $2(33.5)$ \\
Tobacco & $59(65.5)$ & $17(19.0)$ & $14(15.5)$ \\
Yes & & & \\
No & & & \\
\hline
\end{tabular}

Source: Data collected by means of a questionnaire.

There was greater knowledge about the absence of seroconversion among those aged between 31 and 40 years old (23.1\%) and females (63.6\%). Regarding those who did not know how to inform about their seroconversion, the majority (33.3\%) were individuals over 51 years old, $25 \%$ were men and $16.6 \%$ were white. The black ethnic group had more individuals with knowledge about their seroconversion (4/66.7\%).

Alcohol consumption was reported by 6 employees, 2 (33.3\%) of whom had knowledge of seroconversion, $3(50.0 \%)$ claimed not to have antibodies against hepatitis B and 1 (16.7\%) did not know about his seroconversion. Still, $70.7 \%$ (41) reported that they did not use alcohol and had reactive antibodies.

When asked about their knowledge of the presence of immunity to HBV, of the 96 clinic employees $62(64.6 \%)$ claimed to be immune, $18(18.7 \%)$ claimed not to be immune and $16(16.7 \%)$ did not know how to inform. This data was divergent when the anti-HBs tests were verified, where the percentage of immunized reagents was 87 (90.6\%) and of non-reactive 9 (9.4\%). Of the 96 participating professionals, 85 reported having completed the complete vaccination with three doses for hepatitis $B$, which corresponded to $88.5 \%$.

The main risk factors and the frequency in which the clinic's employees are currently exposed are described in Table 2.

When asked about knowledge about hepatitis, it was found that $34(18.9 \%)$ individuals reported using condoms as a preventive measure, $31(17.3 \%)$ reported having no knowledge about the infection, $28(15,6 \%)$ reported the main forms of transmission, and $19(10.5 \%)$ cited vaccination as a means of prevention.
Table 2. Factors associated with the exposure to the hepatitis $B$ virus in professionals working in a private clinic in Cascavel, PR

\begin{tabular}{lc}
\hline Risk factors & $\begin{array}{c}\text { Number of people } \\
\mathbf{n}(\%)\end{array}$ \\
\hline Number of sex partners (last 12 months) & \\
$\leq 1$ & $86(89.5)$ \\
$>1$ & $10(10.5)$ \\
Use of condom & \\
Yes & $24(25.0)$ \\
No & $73(75.0)$ \\
Immunity & \\
Yes & $62(64.6)$ \\
No & $18(18.7)$ \\
Does not know & $16(16.7)$ \\
Hepatitis B or C carrier & \\
Yes & $6(6.25)$ \\
No & $84(87.5)$ \\
Does not know & $6(6.2)$ \\
Home contact & \\
Yes & $5(5.2)$ \\
No & $82(85.4)$ \\
Does not know & $9(9.4)$ \\
Sexual contact & \\
Yes & $3(3.2)$ \\
No & $87(90.6)$ \\
Does not know & $6(6.2)$ \\
Occupational contact & \\
Yes & $25(26.0)$ \\
No & $46(48.0)$ \\
Does not know & $25(26.0)$ \\
Tatoos/Piercings & \\
Yes & $29(31.2)$ \\
No & $64(68.8)$ \\
Accident with biological material \\
Yes & $13(13.5)$ \\
No & $83(86.5)$ \\
\hline Source Colected \\
\end{tabular}

Source: Collected data.

In relation to men and women, women demonstrated greater knowledge about the infection. The lack of knowledge in the population reinforces the need for educational actions so that they can increase their knowledge in relation to hepatitis B and adopt preventive measures regarding their health.

It is also important to note that inadequate knowledge can also be associated with the participants' schooling. As observed in the present study, 9 (28.1\%) participants without any knowledge about HBV infection had only a fundamental level of education; in contrast, $4(12.5 \%)$ employees who did not demonstrate any knowledge had a higher education. Individuals with a technical level showed greater knowledge (54.5\%), and the professionals who work in the clinic with the greatest exposure are Nursing Technicians, who have direct contact with patients and administer intravenous or intramuscular medications.

When comparing the number of employees with full knowledge to those with partial knowledge about hepatitis $B$, it was found that there is a significant difference between age, schooling and, among those who have suffered accidents with biological material, when comparing those who have partial knowledge regarding hepatitis B to those with no knowledge, there is a significant difference in relation to all the parameters, except for the number of employees who have tattoos/piercings, as shown in Table 3. 
Table 3. Correlation between sociodemographic characteristics of the employees working in a private clinic located in Cascavel, PR and reported knowledge about hepatitis $\mathrm{B}$

\begin{tabular}{|c|c|c|c|c|c|}
\hline Characteristics & $\begin{array}{c}\text { Full knowledge about } \\
\text { Hepatitis B } \\
\text { n (\%) }\end{array}$ & $\begin{array}{c}\text { Partial knowledge about } \\
\text { Hepatitis B } \\
\text { n (\%) }\end{array}$ & p-value* & $\begin{array}{c}\text { No knowledge about } \\
\text { Hepatitis B } \\
\text { n (\%) }\end{array}$ & p-value** \\
\hline \multicolumn{6}{|l|}{ Age (years old) } \\
\hline $20-30$ & $9(30.0)$ & 7 (18.4) & \multirow[t]{4}{*}{$<0.001$} & 5 (17.8) & \multirow[t]{4}{*}{$<0.001$} \\
\hline $31-40$ & $9(30.0)$ & $18(47.4)$ & & $12(42.9)$ & \\
\hline $41-50$ & $10(33.3)$ & $10(26.3)$ & & $10(35.7)$ & \\
\hline$\leq 51$ & $2(6.7)$ & 3 (7.9) & & $1(3.6)$ & \\
\hline \multicolumn{6}{|l|}{ Gender } \\
\hline Male & $1(3.7)$ & $3(7.9)$ & \multirow[t]{2}{*}{0.229} & $4(12.9)$ & \multirow[t]{2}{*}{0.020} \\
\hline Female & $26(96.3)$ & 35 (92.1) & & $27(87.1)$ & \\
\hline \multicolumn{6}{|l|}{ Ethnicity } \\
\hline White & $20(80.0)$ & $29(70.7)$ & \multirow[t]{4}{*}{0.433} & $17(56.7)$ & \multirow[t]{4}{*}{0.006} \\
\hline Black & $1(4.0)$ & $2(4.9)$ & & $3(10.0)$ & \\
\hline Mixed & $4(16.0)$ & $10(24.4)$ & & $9(30.0)$ & \\
\hline Others & $0(0.0)$ & $0(0.0)$ & & $1(3.3)$ & \\
\hline \multicolumn{6}{|l|}{ Schooling } \\
\hline Elementary & $0(0.0)$ & 5 (11.9) & \multirow[t]{4}{*}{$<0.001$} & $9(28.1)$ & \multirow[t]{4}{*}{$<0.001$} \\
\hline High School & $2(9.1)$ & $12(28.6)$ & & $11(34.4)$ & \\
\hline Technical & $12(54.5)$ & $17(40.5)$ & & $8(25.0)$ & \\
\hline Higher & $8(36.4)$ & $8(19.0)$ & & $4(12.5)$ & \\
\hline \multicolumn{6}{|c|}{ Tatoos/Piercings } \\
\hline Yes & $6(30.0)$ & $16(35.5)$ & \multirow[t]{2}{*}{0.529} & 7 (22.6) & \multirow[t]{2}{*}{0.304} \\
\hline No & $14(70.0)$ & $29(64.5)$ & & $24(77.4)$ & \\
\hline \multicolumn{6}{|c|}{ Accident with biological material } \\
\hline Yes & $6(27.3)$ & $4(9.1)$ & \multirow[t]{2}{*}{0.016} & $3(10.0)$ & \multirow[t]{2}{*}{0.003} \\
\hline No & $16(72.7)$ & 40 (90.9) & & $27(90.0)$ & \\
\hline
\end{tabular}

Source: Collected data. ${ }^{*}$-value: statistical comparison between total knowledge about hepatitis B and partial knowledge about hepatitis B. ${ }^{* *}$-value: statistical comparison between partial knowledge about hepatitis B and no knowledge about hepatitis B

Thirteen participants reported having suffered an accident with biological material, of whom 6 (27.3\%) had full knowledge about hepatitis $\mathrm{B}$ like its transmission, prevention, diagnosis, vaccination and characteristics, 4 (9.1\%) had partial knowledge and 3 (10.0\%) had no knowledge. Situations like these generate risk, because the individual who suffered an accident at work did not have knowledge of the proportion of risk due to exposure that ended up having contact.

\section{Discussion}

According to a research study developed by Maia et al (2011), it was identified that, in hospital professionals, the prevalence of immunity to hepatitis B was $93.7 \%$ among the nursing professionals in the private service, and $86.2 \%$ among the same professionals from the public service ${ }^{13}$.

The population of the present study was predominantly female, which corresponded to $91.6 \%$ (88) of the total sample. These data are similar to a work developed in 2011 , which identified $81.5 \%$ of female professionals working in the health area $^{8}$. This is justified by the greater number of women seeking better remuneration and placement in the labor market.

It was found that there was a higher incidence of hepatitis $B$ virus markers (except anti-HBs) in individuals who make daily use of alcohol than in healthy individuals ${ }^{14}$. The results of diverse epidemiological studies allow to admit that the consumption of "small doses" of alcohol, for long periods, could favor the development of cirrhosis from non-alcoholic liver disease, and found that the prognosis of acute hepatitis by the B virus is worse in alcoholics ${ }^{14,15}$.

Knowledge about immunity has already been discussed and it has been reported that the health professionals belong to a group that may have their vulnerability to the virus increased in circumstances where they present risky behaviors such as unsafe practices when handling infected biological material and contact with the patient and his fluids, in addition to the hypothesis of the lack of seroconversion identification through the anti-HBs immunological test ${ }^{16}$.

Of the participating professionals, $88.5 \%$ reported having completed the complete vaccination for hepatitis B. In 2017, Barbosa et al (2017) identified in their study a percentage of $84.3 \%$ of the total health professionals who claimed to have completed the full immunization schedule three doses ${ }^{17}$.

Currently, it is known that the best form of prevention against hepatitis $B$ is vaccination. After the completion of the three doses of the vaccine, which corresponds to the full vaccination schedule, it appears that 5 to $10 \%$ of the population does not produce antibodies, which is diagnosed by means of the anti-HBs test ${ }^{9}$; therefore, the reinforcement is recommended in these cases ${ }^{15,18}$.

In a study developed by Livramento et al (2009), 43.0\% of the participants had seroconversion after the first dose of the vaccine ${ }^{19}$. In another study, when assessing the vaccination status of the population, $82.2 \%$ had a complete schedule (3 doses), 3.2\% had an incomplete schedule ( 1 or 2 doses), $12.5 \%$ were unaware of 
their vaccination status and $2.1 \%$ received more than 3 doses due to having suffered an accident with biological material or for not having seroconversion ${ }^{17}$.

In some studies, it was found that approximately 30\% of the participants had knowledge of one or more cases of hepatitis in the family environment ${ }^{19,20}$. The presence of an HBV carrier in the family may represent a risk factor for exposure to the virus, since more than $20 \%$ of the participants have the habit of drinking chimarrão and similar drinks with family and friends, which can facilitate contact with saliva and, consequently, with blood, which can carry the virus ${ }^{20}$.

Among the employees, 6 (6.25\%) claimed to be carriers of the hepatitis B virus. A survey carried out in 2014 identified a prevalence of HBV of $3.5 \%$ among health professionals working in a clinic ${ }^{20}$.

When asked about some risk factors for acquiring hepatitis B, $3(3.15 \%)$ reported sexual contact with a person with the infection and $75.0 \%(73)$ of the population reported not using condoms, which is a risk factor for exposure to hepatitis B and many other Sexually Transmitted Infections (STIS). Regarding sexual contact and exposure with HBV or HCV, around 55\% of the people with a 'Yes' answer were under 40 years of age and could transmit and acquire the disease to/from their partners without having knowledge of this fact ${ }^{21}$.

Adults who have unprotected sexual activity are considered the main source of transmission of the hepatitis B virus; however, competent serum vaccinated individuals who end up naturally re-exposed to $\mathrm{HBV}$, have an increase in anti-HBs titers, which is justified due to their immune memory. However, safe sex is a contributing factor for the prevention of hepatitis B and other STIs 22,23 .

Unlike other work settings, hospitals are places where there is an increased exposure to the health professionals due to the care provided. A wide variety of materials are used which are often in direct contact with biological products, especially those from patients, making professionals constantly predisposed to contamination and the risk of exposure ${ }^{16}$. Occupational contact with patients with hepatitis B was indicated in $25(26.0 \%)$ employees and it is inevitable; however, the practice of safety and the correct use of personal protective equipment minimizes the risk of contamination. Still, 25 (26.0\%) professionals claimed not to know how to inform about occupational contact and $46(48.0 \%)$, that is, the majority, reported not having contact with hepatitis $B$ patients at work.

To avoid occupational exposure, vaccination is the safest way to prevent the transmission of the HBV infection ${ }^{24}$. Immunization against hepatitis $B$ and adequate post-exposure care are essential in an occupational accident prevention program ${ }^{24,25}$

Other risk factors are tattoos and piercings, which were reported by 29 (31.2\%) employees. These can be a form of exposure to the hepatitis B virus when sterile or disposable materials are not used. As explained by Ferreira et al (2014), both the placement of a piercing and the application of a tattoo can cause complications such as infection or bleeding at the site of its insertion, which generates a risk of transmission of HIV, hepatitis $B$ and $C^{26}$.

In a study carried out by Barbosa et al (2017), when asked about the forms of transmission of hepatitis B, $96.9 \%$ of the participants said that the virus is present in blood and body fluids and $3.1 \%$ did not know how to answer ${ }^{17}$. Only 28 (15.6\%) of the 96 employees reported some form of transmission of hepatitis B in this study. Still, 31 (17.3\%) claimed to have no knowledge about hepatitis.

HBV transmission occurs through contact with blood or other bodily secretions. Thus, transmission can occur through sexual intercourse, blood transfusions and/or blood products, use of injectable drugs, usually through shared syringes and needles, mother-child transmission, through prolonged interpersonal contact and accidents with sharps, the greatest exposure of which is of health professionals ${ }^{24,26}$. In the present study, only 34 (18.9\%) employees reported using condoms as a form of protection and 29 (16.1\%) commented on the use of PPE.

Currently, hepatitis B is considered to be the infectious disease most likely to be acquired by health professionals in the performance of their work activities ${ }^{27}$. Regarding the professionals' knowledge in relation to biosafety measures, the majority, that is, $97.9 \%$ stated that they have PPE to carry out their activities, $89.6 \%$ answered that they received guidance on the correct use of these PPE and $81.2 \%$ said they use the PPE correctly $25,26,27$.

Most diseases and accidents at work could be prevented through preventive health, safety at work and planned training programs involving collective and individual protection measures, also through the use of Collective Protection Equipment (CPE) and PPE, which constitute safety and protection for the worker ${ }^{25,28}$.

The data presented above must be analyzed considering some limitations: the sample is small, which can generate results not consistent with the general reality of hospitals in the municipality, in addition, the data were collected through questionnaires during working hours, which can bias the study due to lack of attention or the need to finish quickly due to the need to return to work. Also, the clinic is private, which may not describe what is seen in public hospitals. However, we believe that our study can bring an important reality in relation to the little knowledge that some professionals still have considering that they are exposed to risks as important as the transmission of hepatitis $B$, an infection so well known today.

\section{Conclusion}

The present study showed that knowledge about the hepatitis B virus infection is insufficient for some employees, considering the severity of the infection and the risk of transmission to which they are exposed. This fact reinforces the need for training, through constant training on the risks of transmission of microorganisms present in the blood, such as HBV, seeking to prevent occupational accidents, encouraging the use of individual and collective protective equipment, passing on information about the importance of vaccination against hepatitis $B$ and serological monitoring in order to assist in the knowledge about the presence of protective antibodies.

\section{Funding sources}

There was no funding from any public or private agency.

\section{Collaborators}

ADB carried out the design of the project, collection, analysis and interpretation of data and writing of the article; CMS and JJVT participated in the relevant critical review of the intellectual content and final approval of the version; LDP participated in the design of the project, writing of the article and critical review.

\section{Acknowledgments}

The authors would like to thank the coordinators of the Gênesis Hospital in Cascavel, Paraná. 


\section{Conflict of interest statement}

The authors declare that there is no conflict of interest in this article.

\section{References}

1. Organização Mundial da Saúde (OMS). Global health sector strategy on viral hepatitis 2016-2021. Towards ending viral hepatites. 2016. Available from http://www.who.int/iris/ handle/10665/246177. Accessed on October 31, 2018.

2. Organização Mundial Da Saúde (OMS) OMS diz que hepatite atinge 400 milhões de pessoas em todo o planeta. Available from http://agenciabrasil.ebc.com.br. Accessed on on March 252018.

3. Brasil. Ministério da Saúde. Secretaria de Vigilância em Saúde. Departamento de DST, Aids e Hepatites Virais. Protocolo Clínico e Diretrizes Terapêuticas para Hepatite B e Coinfecções/ Ministério da Saúde, Secretaria de Vigilância em Saúde, Departamento de DST, Aids e Hepatites Virais. Brasília, 2017.

4. Brasil. Ministério da Saúde. Boletim Epidemiológico Secretaria de Vigilância em Saúde, 2018.

5. Fonseca JCF. História natural da hepatite crônica B. R. Rev. Soc. Bras. Ave. Trop. 2007; 40(6):672-677.

6. Costa FM, Martins AMEBL, Santos Neto PE, et al. Is vaccination against hepatitis $B$ a reality among Primary Health Care workers? Rev Latino-Am Enfermagem. 2013; 21(1):316-24.

7. Ministério da Saúde (Br). Coordenação Geral de Saúde do Trabalhador. Exposição a materiais biológicos. Brasília (DF): Ministério da Saúde; 2011.

8. Oliveira VC, Guimarães EAA, Souza DAS, et al. Situação vacinal e sorológica para hepatite $B$ em profissionais da Estratégia Saúde da Família. Rev. Rene. 2011; 12: 960-965.

9. Fraguas SA, Silvino ZR, Flach DMAM, et al. Immunization against Hepatitis $B$ : a matter of occupational health nursing. Rev. Pesq. Cuid. Complete Online. 2013; 5(1):3150-3158.

10. Pyrsopoulos NT. Hepatitis B. Medscape Reference. 2011

11. Lima BFL, Waffae MC, Figueiredo EN, et al. Occupational infection by the hepatitis $b$ virus: risk and prevention measures. Journal of Human Growth and Development. 2013; 23(2):184-9.

12. Morais LQ, Motta-Castro ARC, Frota OP, et al. Hepatite B em profissionais de enfermagem: prevalência e fatores ocupacionais de risco. Rev enferm UERJ. 2016;24(3):1-6.

13. Maia LS, Maia LS, Cruvinel KPS. Transmissão das hepatites B e C. Rev. Enf. Integr. 2011; 4(1):716-730.

14. Mincis M, Mincis R. Como diagnosticar e tratar doença hepática alcoólica. Grupo Editorial Moreira Junior. 2006. Available from http://www. moreirajr.com.br/revistas.asp?fase=r003\&id_ materia=3134. Accessed on on November 20, 2018.

15. Santos AKP, Almeida DJ, Santos IS, et al. O conhecimento sobre hepatites B e C dos estudantes de uma escola particular do município de Vitória da Conquista - BA. Id on Line- Revista Multidisciplinar e de Psicologia. 2017; 11(36):112-123.

16. Pinheiro J, Zeitoune RCG. O Profissional de Enfermagem e a Realização do Teste Sorológico para Hepatite B. Rev. Enferm. UERJ. 2009; 17(1):30-34.
17. Barbosa ASAA, Salotti SRA, Silva SMUR. Nível de conhecimento sobre Hepatite $B$, estado vacinal e medidas de biossegurança de profissionais de enfermagem. Rev. Epidemiol. Control. Infec. 2017; 7(2):107-112.

18. Schillie S, Murphy TV, Sawyer M, et al. CDC guidance for evaluatin health-care personnel for hepatitis B virus protection and for administering postexposure management. MMWR. 2013; 62(10): $1-24$.

19. Livramento AD, Cordova CMM, Treitinger CAS. Avaliação do nível de conhecimento de adolescentes a respeito da transmissão e prevenção das hepatites B e C. Rev. Patol. Trop. 2009; 38 (3): 155-163.

20. Lima LPE, Barreto MJ, Manso CAC, et al. Prevalência de hepatite $B$ e C em caminhoneiros em trânsito pelo Vale do Aço, Minas Gerais. BJSCR. 2014; 6(3):05-09.

21. Farias N, Souza I; Coelho DM; et al. Coinfecção pelos vírus das hepatites B ou C e da imunodeficiência adquirida: estudo exploratório no estado de São Paulo, Brasil, 2007 a 2010. Epidemiol. Serv. Saúde. 2012; 21(3):475-486.

22. Bulkow LR, Wainueright RB, Mcmahon BJ, et al. Increased levels of antibody to hepatitis bsurface antigen in a immunized population. Clin. Infect. 1998; 26: 933-1058.

23. Gir E, Caffer Netto J; Malaguti SE, et al. Acidente com material biológico e vacinação contra hepatite $B$ entre graduandos da área da saúde. Rev Latino-am Enfermagem. 2008; 16(3): 401404.

24. Ribeiro PCP, Olliveira PBR. Culto ao corpo: beleza ou doença? Adolesc. Saúde. 2011; 8(3): 63-69.

25. Soares VS, Brune MFSS, Faria AA. Prevalência de hepatites B e $C$ em profissionais da saúde de um hospital em Barra do Garças/MT. Rev. Eletr. Univar. 2014; 2(12):84-89.

26. Ferreira AR, Fagundes EDT, Queiroz TCN, et al. Hepatites virais A, B e C em crianças e adolescentes. Rev Med Minas Gerais. 2014; 24 (Supl 2): S46-S60.

27. Soares DM, Lima CA, Soares FMC, et al. Enfermagem: realidade da imunização contra hepatite $B$ de um hospital do norte de Minas Gerais. Esc. Anna Nery. 2015; 19(4):692-701.

28. Carvalho GM. Enfermagem do Trabalho. São Paulo. 1 ed.; 2001. 